\title{
MONEY MARKET EQUILIBRIUM IN THE CZECH REPUBLIC
}

\section{Jana Juriová*}

\begin{abstract}
:
This paper examines the theoretical concept of equilibrium in the money market that is empirically verified for the economy of the Czech Republic. The subject of the analysis is the relationship defining equilibrium in the domestic money market, i.e. when money demand corresponds to the money supply in the economy. The main objective is to determine whether such a long-term equilibrium relationship exists by verifying this assumption on real data for the Czech economy. The Johansen cointegration approach is applied for modelling the money demand function including four domestic macroeconomic indicators: money supply, price level, gross domestic product, and interest rate. The results suggest that the level of real money supply fluctuated around the estimated long-run equilibrium value in the analysed period 2000-2013.
\end{abstract}

Keywords: money market, money supply, money demand, OLS, cointegration, long-run equilibrium, error-correction model

JEL Classification: E41, E47

\section{Introduction}

The primary objective of monetary authorities is to anticipate the demand for money and provide the necessary level of money supply which maintains the desired level of product, employment, and price stability. Aspects of stable money demand function have been known since the time of Friedman (1956) who proposed the rule of fixed money growth in order to achieve price stability. Demand for money is one of the important topics of monetary policy due to its direct connection with the money supply, interest rates, and economic growth. Therefore, the demand for money plays an important role, either directly or indirectly in the implementation of monetary policy. In the current literature, much attention is devoted to study aggregate demand for money, its stability and determinants - particularly income and interest rates. This issue is addressed, for example, in Rao and Kumar (2007), Choi and Jung (2009), Hsing and Jamal (2011), Hossain (2013), Sarwar et al. (2013). Various studies have provided different results and conclusions that do not allow formulating a clear consensus of opinion. On average, however, it seems that in the current global economic situation it is necessary to re-address the stability of money demand function. The most appropriate money supply, which provides a stable estimate of money demand functions, is more broadly defined money supply M2.

The objective of this paper is the modelling of equilibrium in the domestic money market in the Czech Republic (CR), which is determined, on the one hand, by the money

* Jana Juriová, VŠB-Technical University of Ostrava, Faculty of Economics, Ostrava, Czech Republic (jana.juriova@vsb.cz).

This paper was funded by the Student Grant Competition of VŠB - Technical University of Ostrava within the Project No. SP2014/131. 
supply and, on the other hand, by the money demand. In terms of further development of the CR and its sustainable economic growth the examination of the balance in the domestic money market is relevant particularly nowadays.

As demand for money is one of the most popular concepts in theoretical and empirical economics, there exist various forms of money demand functions. The traditional demand function includes only domestic variables and thus exploring traditional money demand focuses mainly on the concept of a closed economy. However, many authors prove that domestic determinants of money demand are superior to foreign factors. It means that after the inclusion of domestic variables the improvement in the explanatory power of the traditional demand function is rarely possible. Considering the various approaches, many studies use cointegration techniques for studying money demand, such as Dreger and Wolters (2014), Kolluri et al. (2012), Hayo (2000), Coenen and Vega (1999). However, there is little literature focused on the analysis of money demand in the countries of Central Europe. For example, Arlt et al. (2001) focused on selected factors influencing the money demand development in the Czech Republic from 1994 to 2000. A premise that the money demand development is in the long-run relationship with the GDP growth and interest rates development was confirmed. Later, Komárek and Melecký (2004) analysed the money demand function for the period 1993-2001. One of their conclusions was that all considered domestic explanatory variables except for inflation, were important determinants of money supply M2.

The paper is organized as follows. The second section describes the theoretical concept of money market equilibrium, the third section contains the econometric methodology used, the fourth section presents and explains the empirical results and the fifth section concludes.

\section{Theoretical Concept}

The theoretical concept of equilibrium in the money market was defined on the basis of traditional economic theory. According to Krugman (2012) the money market is in equilibrium when the money supply in the economy is equal to the aggregate demand for money. Money supply in the economy is controlled by the central bank. The central bank directly controls the amount of money in circulation and also has indirect control over the amount of check deposits issued by private banks. Thus the nominal money supply is given by the decisions of the central bank and commercial banks. For simplicity, we assume that the central bank determines the amount of the money supply $M^{s}$ at a desired level and thus the money supply is an exogenous variable. On the other hand, aggregate money demand is the total demand of all households and firms in the economy. This means that aggregate demand is the sum of individual subjects' demands for money. Based on this consideration, we derive the determinants of aggregate money demand. The first factor of demand at money market is the interest rate. An increase in interest rate causes a decrease in money demand for each economic subject. Aggregate demand for money therefore decreases when interest rate rises, while other conditions remain unchanged (under condition ceteris paribus). Another factor of demand in money market is the price level. The price level in the economy is characterized as a price reference basket of goods and services in the domestic currency. Generally, a reference basket includes standard everyday consumer products such as food, clothing, housing, or even uncommon expenditures, for example, spending on health care and legal fees. If the price level rises, individual households and firms have to spend more 
money to buy the usual basket of goods and services. Therefore, to maintain the same level of liquidity as it was before the price increase, they will need to keep more money. The third factor that determines the aggregate money demand is the real national income. If real gross domestic product (GDP) is growing, it means that the economy has sold more goods and services. This increase in the real value of transactions results in increasing money demand at a given price level. If $P$ denotes the price level, $R$ is the interest rate, and $Y$ is real GDP, then aggregate money demand $M^{d}$ can be expressed as follows:

$$
M^{d}=P . L(R, Y)
$$

where the value of the function $L(R, Y)$ falls when $R$ rises, and rises when $Y$ rises $^{1}$. When expressing the function $L(R, Y)$ it is clear that it is a real aggregate demand for liquidity expressed as the demand for the possession of a certain amount of real purchasing power in liquid form.

Domestic money market equilibrium - MME (2) when the money supply determined by the central bank is equal to the aggregate demand for money, i.e. equilibrium condition in the money market is then as follows:

$$
M^{S}=M^{d} .
$$

After dividing both sides of Equation (2) by the price level $P$ the relationship MME can be expressed in terms of real money supply and real aggregate real money demand as follows:

$$
\frac{M^{s}}{P}=L(R, Y) .
$$

On the basis of Equation (3) the equilibrium interest rate in the economy can be determined. At the current price level $P$ and product level $Y$ the equilibrium interest rate is one at which the aggregate real money demand equals money supply.

This theoretical concept of equilibrium in the money market is further used as a basis for estimating the long-term equilibrium relationship in the money market.

\section{Econometric Methodology - Cointegration Analysis}

The goal of this analysis is to examine the long-term equilibrium in the money market. For analysis, we therefore used cointegration model with multiple variables, which allows examining simultaneously both long-term and short-term relationships between variables. Using this type of model imposes requirements on the specific characteristics of the data. The basic feature that is necessary to verify in the data is stationarity. When applying cointegration model we are most of all interested in integrated time series or the so called unit root processes. Time series is defined as integrated of order $d$, of type $I(d)$ if its $d$-th difference is stationary. In our particular case, if the first differences are sufficient to make time series stationary, these time series are integrated of order one, $I(1)$. Therefore, the first step in the analysis is to determine whether the modelled time series are integrated of type I(1). For this purpose we used Augmented Dickey-Fuller test of unit root (ADF test) to analyse the stationarity of time series which is based on testing of unit root in autoregressive model (Dickey and Fuller, 1979, MacKinnon et al., 1999).

$1 \quad$ Naturally, $L(R, Y)$ rises when $R$ falls, and falls when $Y$ falls. 
If we have a non-stationary time series that are integrated of order one and want to use them to create an econometric model, it is necessary to get rid of nonstationarity in the data, i.e. include their first differences into the model. In this way, however, we lose information about long-term relationships between variables. This can be avoided if we use the cointegration analysis (Hendry, Juselius, 2000, 2001), which allows us to examine the short-term relationships, but also help us to find a long-term cointegration relationship between variables, which can be regarded as an equilibrium. Mathematically, it is such a linear combination of variables which is stationary. In terms of the real economy, this means that between the variables describing the state of the economy an equilibrium state exists to which they always return in the long run. The effect of shock in the economy will cause a short-term imbalance, but over time the economy will again converge to its equilibrium.

When estimating a cointegration model we start with a model of vector autoregression of the order $p-\operatorname{VAR}(p)$ :

$$
y_{t}=A_{1} y_{t-1}+\ldots+A_{p} y_{t-p}+B x_{t}+\varepsilon_{t}
$$

where $y_{t}$ is vector $k x 1$ non-stationary $I(1)$ variables, $x_{t}$ is vector $d x l$ deterministic variables and $\varepsilon_{t}$ is residual variable. The relationship (4) can be rewritten into the form of error correction model (ECM) in the following way:

$$
\begin{gathered}
\Delta y_{t}=\Pi y_{t-1}+\sum_{i=1}^{p-1} \Gamma_{i} \Delta y_{t-i}+B x_{t}+\varepsilon_{t} \\
\Pi=\sum_{i=1}^{p} A_{i}-I, \Gamma_{i}=-\sum_{j=i+1}^{p} A_{j} .
\end{gathered}
$$

Granger's representation theorem (Engle and Granger, 1987) says that if the matrix of coefficients $\Pi$ has reduced rank $r<k$, then there are two $k x r$ matrices $\alpha$ and $\beta$, both with a rank $r$ and $\Pi=\alpha \beta$ and $\beta y$ is of type $\mathrm{I}(0)$. Then the number of cointegration equations is equal to $r$ and each column of the matrix $\beta$ represents one cointegration equation. The coefficients $\alpha$ are correction parameters of EC model. Johansen method is used to estimate the $\Pi$ matrix of the VAR model.

When estimating the VAR model, first we need to determine the appropriate number of lags for the model (the selection of appropriate number of lags can be based for example on Akaike information criterion). If the least squares method is used to estimate the model, we must test also the attributes of residuals from the estimated model (autocorrelation, heteroskedasticity, and normality).

The existence of cointegration relationship between variables in the estimated model can be confirmed by Johansen cointegration test. Johansen cointegration test is used to determine the maximum number of cointegration relationships that may exist between variables. Johansen methodology uses 5 different combinations of test taking into account the constant and deterministic trend in the cointegration equation. The number of cointegration relationships, i.e. the degree of cointegration $r$ is applied as a restriction on the matrix $\Pi$ when estimating the model. 


\section{Empirical Results}

The theoretical concept described in Section 2 was transformed into an econometric model for the purpose of empirical studying of money market equilibrium in the Czech Republic. Given the theoretical specification of determinants of supply and demand in the money market, we consider in the model the time series of the following variables for the Czech economy:

$M_{t}$ money supply M2 according to national definition, in millions of national currency, current prices, seasonally adjusted;

$P_{t} \quad$ harmonized consumer price index $(2005=100)$;

$Y_{t} \quad$ gross domestic product at market prices, in million units of national currency, at constant prices $(2005=100)$, seasonally adjusted;

$R_{t} \quad$ money market interest rate in the Czech Republic, 3-month rate in \%;

Data source: Eurostat

The above series are available quarterly for the period 1996Q1-2013Q4 (72 observations). Time series of money supply and gross domestic product are obtained from Eurostat in seasonally adjusted form and time series of prices and interest rate are seasonally adjusted by the procedure Tramo-Seats. Seasonally adjusted data are used in estimating the following equilibrium relationship:

$$
\frac{M_{t}}{P_{t}}=f\left(R_{t}, Y_{t}\right) \text {. }
$$

Real domestic money supply is determined as the share of nominal money supply $M_{t}$ and price level $P_{t}\left(P_{t}\right.$ represents the domestic price index). Real money demand is a function of domestic real output $Y_{t}$ and domestic nominal interest rate $R_{t}$. According to the quantity theory of money, basic macroeconomic rule for monetary policy says that if money supply grows faster than real product, it leads to inflationary pressures. In developed economies, the central bank supervises the monetary growth in particular by setting interest rates. The growth of interest rate causes rising costs of holding money, resulting in a decrease in the quantity of money in circulation. On this basis, we expect a positive dependence of money supply growth on GDP growth (Figure 1) and a negative dependence on the growth in interest rate (Figure 2). In Figure 1 we can see that the growth trend of monetary base and real GDP is very similar. From Figure 2 it is clear that the relationship between interest rates and the money supply has a negative dependence in the period from 1998Q1, while more stable trend has been visible since around 2000. Given the existence of a structural break at the beginning of the time series in the further analysis we consider a shortened period from 2000 . 

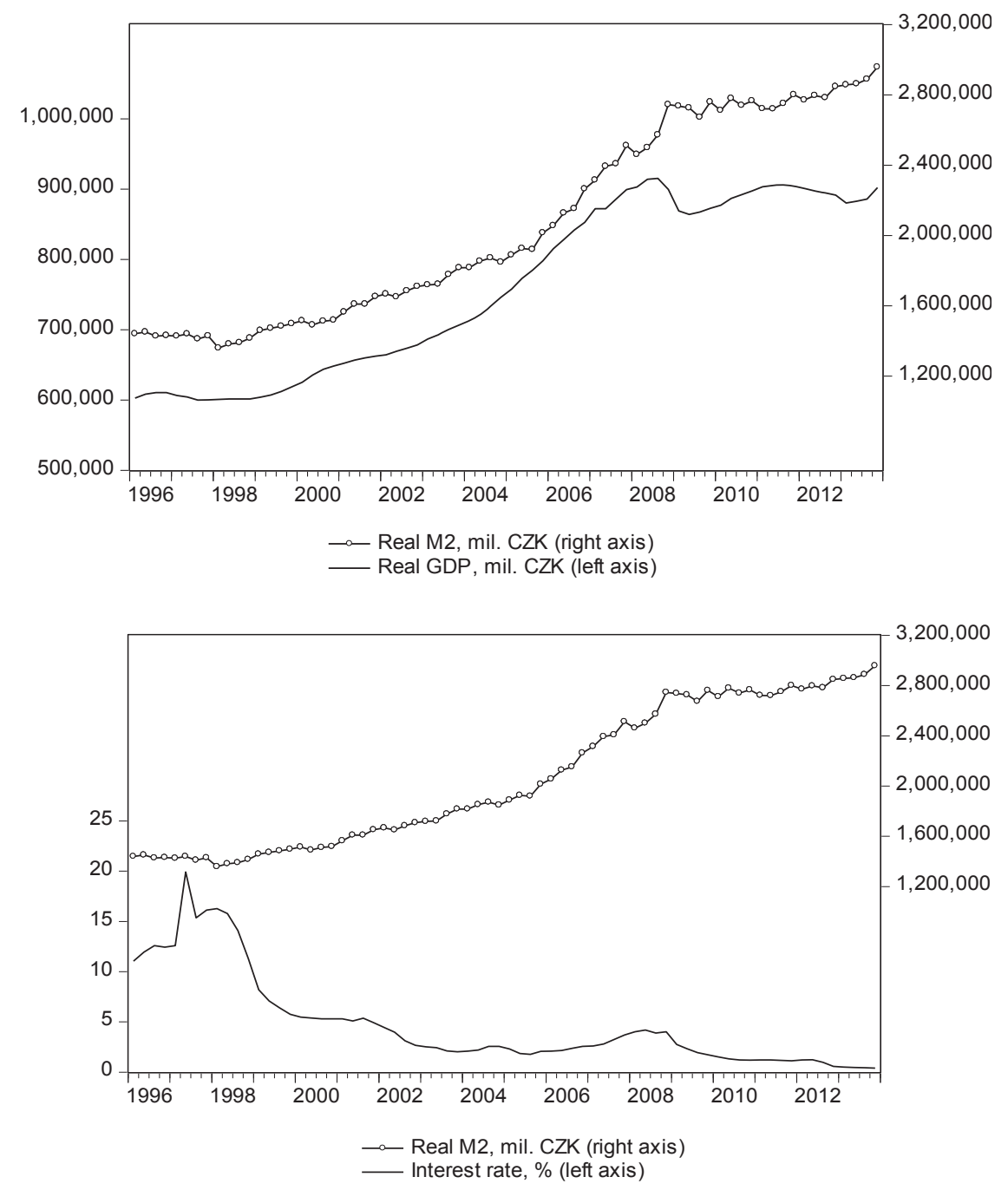

Source: Author's calculations based on data from Eurostat

To determine the long-term equilibrium between variables in the money market, we used co-integration analysis. The information given by non-stationarity in data that can be preserved by using cointegration analysis defines the deviation from the long-run equilibrium. The model based on the imbalance in long-term relationships is also relevant for forecasting in the medium term.

For empirical purposes, we used log-linear approximation of the long-term equilibrium relation (7). Then, long-term relationship has the following form:

$$
m_{t}=\beta_{0}+\beta_{1} r_{t}+\beta_{2} y_{t}+\varepsilon_{t+1}
$$


where $m_{t}=\ln \left(\frac{M_{t}}{P_{t}}\right), y_{t}=\ln \left(Y_{t}\right), r_{t}=\ln \left(1+R_{t}\right)$, and $\varepsilon_{t+1}$ is a random term with normal
distribution.

In the first step, we have to verify that the data are integrated of order one, I(1). For this purpose, the ADF test of unit root was used (Table 1). Based on the graphical analysis given above and the identification of a structural break in the evolution of interest rates, data in the empirical analysis have been shortened for the period since 2000 . The following results of tests and estimates are therefore obtained from the data for the period 2000Q1-2013Q4 (total of 56 observations).

Table 1 | Results of ADF Test of Unit Root

\begin{tabular}{|l|c|c|c|}
\hline variable & $\begin{array}{c}\text { level } \\
\text { trend+constant } \\
\text { t-statistic(sign.)/lags }\end{array}$ & $\begin{array}{c}\text { level } \\
\text { constant } \\
\text { t-statistic(sign.)/lags }\end{array}$ & $\begin{array}{c}\text { 1st difference } \\
\text { constant } \\
\text { t-statistic(sign.)/lags }\end{array}$ \\
\hline $\boldsymbol{m}_{\boldsymbol{t}}$ & $-0.95(0.94) / 0$ & $-0.96(0.76) / 0$ & $-8.37(0.00) / 0$ \\
\hline $\boldsymbol{r}_{\boldsymbol{t}}$ & $-2.05(0.56) / 1$ & $-1.39(0.58) / 1$ & $-4.77(0.00) / 0$ \\
\hline $\boldsymbol{y}_{\boldsymbol{t}}$ & $-1.34(0.87) / 1$ & $-1.53(0.51) / 1$ & $-3.35(0.02) / 0$ \\
\hline
\end{tabular}

Source: Author's calculations

The unit root hypothesis has been confirmed for all the analysed variables. It means that the time series of the original variables are non-stationary, but their first differences are stationary at the significance level of $2 \%$. Therefore, we can say that the variables are integrated of order one, type of $I(1)$.

In the next step we verified by the least squares method (OLS) whether the data actually show the expected positive dependence of the real money supply on real GDP and the negative dependence on interest rate. Based on conflicting trends in the time series of interest rate particularly at the beginning of the analysed period, we conducted regression analysis for a shortened period from 2000Q1 to 2013Q4, i.e. for 56 observations. OLS results (in Table 2) confirmed that between the variables in the analysed period the directions of dependencies are in accordance with the theoretical assumptions given above. However, the autocorrelation of residuals is strong (Durbin-Watson statistic achieved the value of 0.159).

Table 2 | OLS Estimate of Real Money Supply

Endogenous variable: $\boldsymbol{m}_{t}$

\begin{tabular}{|l|c|c|c|c|}
\hline Exogenous variable & Estimated parameter $\boldsymbol{\beta}_{\boldsymbol{i}}$ & Stand. Error & t-Statistic (Prob.) & R-squared \\
\hline $\boldsymbol{r}_{\boldsymbol{t}}$ & -2.0946 & 0.7101 & $-2.9499(0.00)$ & 0.9402 \\
\hline $\boldsymbol{y}_{\boldsymbol{t}}$ & 1.5472 & 0.0783 & $19.7646(0.00)$ & \\
\hline constant & -6.3723 & 1.0757 & $-5.9241(0.00)$ & \\
\hline
\end{tabular}

Source: Author's calculations 
In the next step we estimated three variables VAR model with two lags. The suitability of the chosen lag order was confirmed by several criterions - Akaike information criterion, LR test statistic and final prediction error (more on the tests can be found in Lütkepohl, 1991). The results of lag order selection tests are given in the Annex. The quality of the estimated model was verified by stability test (by means of the inverse roots of the characteristic AR polynomial; see Lütkepohl, 1991) and residual tests - results of all the tests are also given in the Appendix. Autocorrelation of residuals was tested by LM test (Johansen, 1995) and multivariate Portmanteau test (Lütkepohl, 1991). Multivariate extension of Jarque-Berra test was used for testing of residual normality (with Cholesky of covariance factorization as in Lütkepohl, 1991), and White's test was used for testing the presence of residual heteroskedasticity (White, 1980 extended by Doornik, 1995). Most of requirements for residuals of the model were met. We found no evidence of serial correlation and heteroskedasticity. In case of normality we suppose that residuals are asymptotically normal.

Subsequently, the analysis was performed using the Johansen cointegration test, which indicates one cointegration vector (Table 3). Table 3 summarizes all 5 test possibilities that can be considered when estimating the cointegration equation. The existence of cointegration relationship is evaluated on the basis of critical values of MacKinnon-HaugMichelis (1999) at the 5\% significance level.

Table 3 | Johansen Cointegration Test

\begin{tabular}{|l|c|c|c|c|c|}
\hline Data Trend: & None & None & Linear & Linear & Quadratic \\
\hline \multirow{2}{*}{ Test Type } & No Intercept & Intercept & Intercept & Intercept & Intercept \\
\cline { 2 - 6 } & No Trend & No Trend & No Trend & Trend & Trend \\
\hline Trace & 1 & 1 & 1 & 0 & 0 \\
\hline Max-Eig & 1 & 1 & 0 & 0 & 0 \\
\hline
\end{tabular}

Source: Author's calculations

Based on the results of the Johansen cointegration test, we verified first 3 options of cointegration equation (considering intercept and no trend). Our final estimates of parameters that are consistent with economic theory are obtained including the intercept into the long-term cointegration equation. The results of estimate are presented in Table 4. The estimates of cointegration parameters are included in the matrix $\beta$ and the error correction coefficients with their standard errors in parentheses are shown in the matrix $\alpha$. 


\section{Model without restrictions}

\begin{tabular}{|c|c|c|c|}
\hline Cointegration Equation: & $\boldsymbol{\beta}_{i}$ & & \\
\hline$m(-1)$ & 1 & & \\
\hline$r(-1)$ & $\begin{array}{l}1.8934 \\
(0.924)\end{array}$ & & \\
\hline$y(-1)$ & $\begin{array}{c}-1.3593 \\
(0.1156)\end{array}$ & & \\
\hline c & $\begin{array}{l}3.7141 \\
(15927)\end{array}$ & & \\
\hline Error Correction: & $D(m)$ & $D(r)$ & $D(y)$ \\
\hline$a_{i}$ & $\begin{array}{l}-0.1674 \\
(0.0346)\end{array}$ & $\begin{array}{c}0.0056 \\
(0.0056)\end{array}$ & $\begin{array}{r}-0.0419 \\
(0.0156)\end{array}$ \\
\hline
\end{tabular}

Source: Author's calculations

The resulting cointegration equation modelling the long-term equilibrium in the money market is given by the following estimated equation:

$$
m^{*}=-3.7141-1.8934 r_{t}+1.3593 y_{t} .
$$

It follows that the long-term elasticity of the real domestic product to the real supply of money is about 1.4 in accordance with the quantitative theory of money, i.e. if the real domestic product grows, also the real money supply increases. The long-term elasticity of interest rate on the real money supply is negative, in line with our expectations, i.e. the demand for real money is a decreasing function of interest rate.

By backward transformation of variables we get the following relationship:

$$
\frac{M_{t}}{P_{t}}=\exp (-3.7141) \cdot \exp \left(-1.8934 R_{t}\right) \cdot \exp \left(1.3593 Y_{t}\right) \text {. }
$$

The following Figure 3 compares the empirically established real money supply with its estimated long-term equilibrium value. 


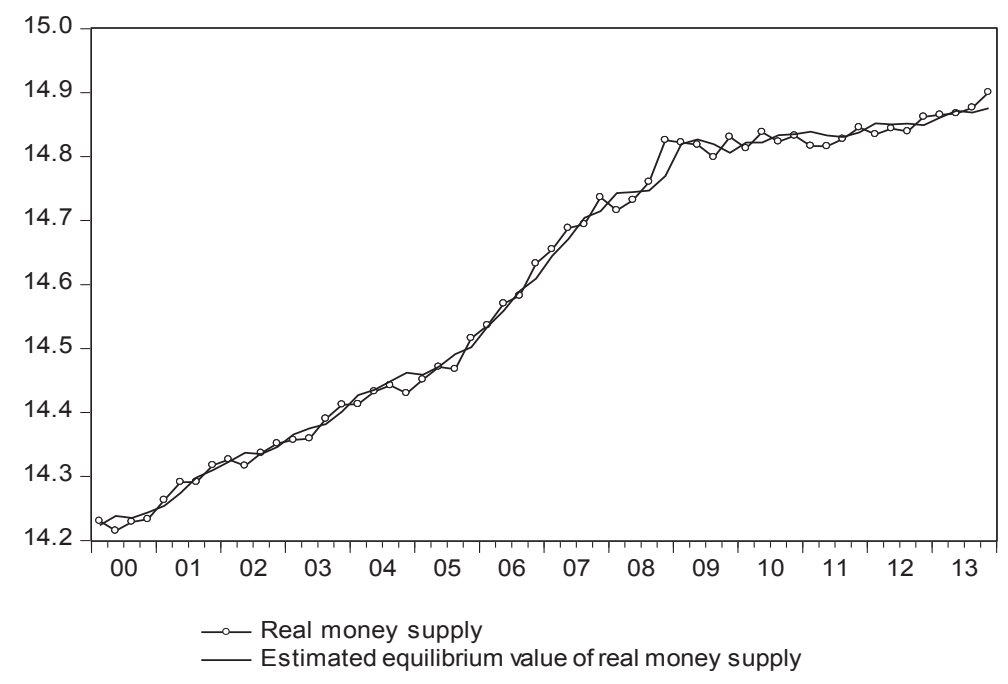

Source: Author's calculations based on data from Eurostat

During the period until global financial crisis at the end of 2008 we can see almost stable growth of money supply in the Czech Republic. From 2009 the dynamics of money supply growth decelerated. Excessive fiscal consolidation in the last post-crisis period hampered the domestic demand, which was reflected in the negative economic growth in 2012 and 2013 and there was weak impulse for money demand. At the end of 2013, however, we can follow a slight acceleration of the real money supply growth rate.

\section{Figure 4 | Deviation of Real Money Supply from Its Long-Term Equilibrium in CR}

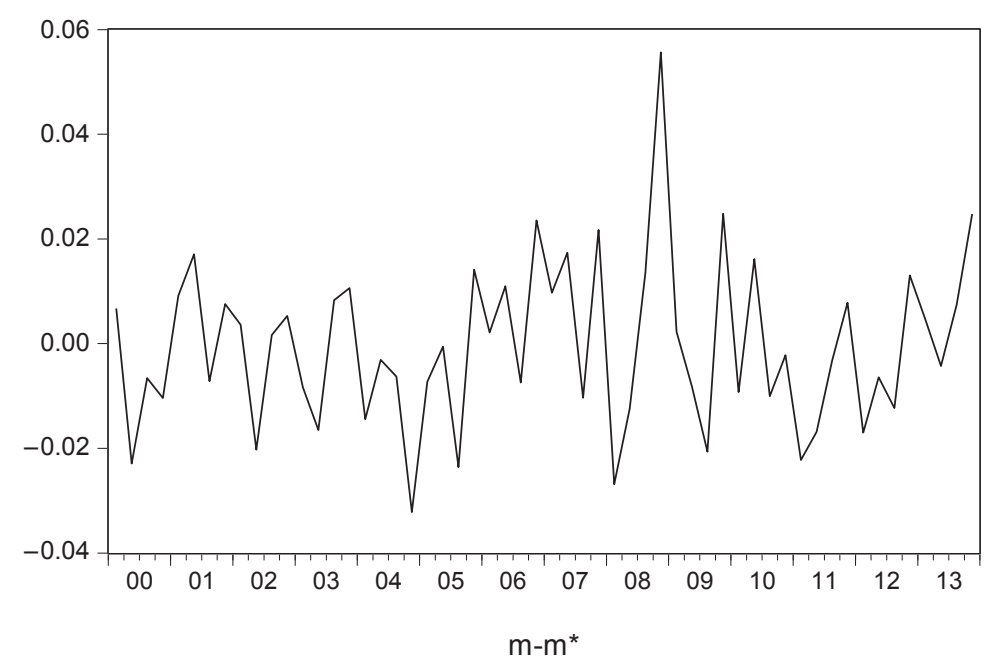

Source: Author's calculations based on data from Eurostat 
We can see that for most of the analysed period the real money supply was very close to the estimated equilibrium demand for money. Particular deviations can be analysed more closely in the Figure 4 where there is depicted the deviation of real money supply from its estimated long-run value, i.e. the money market equilibrium. It is obvious that the highest deviation is recorded in the fourth quarter of 2008 that was affected by the global financial crisis. In this period the real money supply achieved its peak mainly due to the higher growth dynamics of money in circulation (probably the most liquid money) and also due to the low inflation in the Czech Republic at the end of 2008. The beginning of 2009 is connected with steep fall of money supply as a reaction to falling demand for money, which was followed by return to its long-term equilibrium value in the next period.

\section{Conclusion}

The empirical analysis of the relationship between macroeconomic variables in the Czech Republic confirmed the existence of a long-term equilibrium relationship in the domestic money market. The results obtained on quarterly data for the period 2000-2013 indicate the presence of a long-term relationship between the real money supply M2, real output, and nominal interest rate. The results confirmed the significant influence of domestic product and interest rate on the money supply. The variables in the money demand function bear the theoretically expected signs, and the long-run coefficients are plausible. This means that real GDP is positively correlated with the real money supply, while the interest rate is in a negative relationship.

The analysis showed that in the period 2000-2013, the level of real money supply fluctuated around the estimated long-run equilibrium value. Above the equilibrium level the money supply got higher only for a short period after the financial crisis, when money demand declined. The results indicate that the evolution of M2 is still in line with money demand, even when observations from the global financial crisis are included. 


\section{Appendix}

\section{Results of Testing VAR(2) Model Lag Order Selection Test}

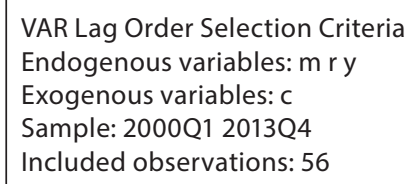

\begin{tabular}{|c|c|c|c|c|c|}
\hline Lag & LogL & LR & FPE & AIC & SC \\
\hline $\mathbf{0}$ & 291.5574 & NA & $6.71 \mathrm{e}-09$ & -10.30562 & -10.19712 \\
\hline $\mathbf{1}$ & 607.5532 & 586.8493 & $1.16 \mathrm{e}-13$ & -21.26976 & $-20.83575^{*}$ \\
\hline $\mathbf{2}$ & 619.1775 & $20.34252^{*}$ & $1.06 \mathrm{e}-13^{*}$ & $-21.36348^{*}$ & -20.60397 \\
\hline $\mathbf{3}$ & 621.5392 & 3.880076 & $1.36 \mathrm{e}-13$ & -21.12640 & -20.04139 \\
\hline $\mathbf{4}$ & 630.2119 & 13.31877 & $1.39 \mathrm{e}-13$ & -21.11471 & -19.70420 \\
\hline $\mathbf{5}$ & 639.9812 & 13.95606 & $1.39 \mathrm{e}-13$ & -21.14218 & -19.40617 \\
\hline
\end{tabular}

Note: * indicates lag order selected by the criterion

LR: sequential modified LR test statistic (each test at $5 \%$ level)

FPE: Final prediction error

AIC: Akaike information criterion

SC: Schwarz information criterion

HQ: Hannan-Quinn information criterion

\section{VAR Stability Condition Check}

\begin{tabular}{|c|l|}
$\begin{array}{l}\text { Roots of Characteristic Polynomial } \\
\text { Endogenous variables: } \mathrm{m} r \mathrm{y} \\
\text { Exogenous variables: } \mathrm{C} \\
\text { Lag specification: } 12\end{array}$ \\
\hline Root & Modulus \\
\hline 0.977582 & 0.977582 \\
\hline $0.890594-0.153519 i$ & 0.903729 \\
\hline $0.890594+0.153519 i$ & 0.903729 \\
\hline 0.547132 & 0.547132 \\
\hline-0.348468 & 0.348468 \\
\hline 0.179486 & 0.179486 \\
\hline
\end{tabular}

Note: No root lies outside the unit circle.

VAR satisfies the stability condition. 


\section{Residual Autocorrelation Tests}

\section{VAR Residual Serial Correlation LM Tests}

Null Hypothesis: no serial correlation at lag order $\mathrm{h}$

Sample: 2000Q1 2013Q4

Included observations: 56

\begin{tabular}{|c|c|c|}
\hline Lags & LM-Stat & Prob \\
\hline $\mathbf{1}$ & 3.395419 & 0.9465 \\
\hline $\mathbf{2}$ & 6.053109 & 0.7346 \\
\hline
\end{tabular}

Note: Probs from chi-square with $9 \mathrm{df}$

VAR Residual Portmanteau Tests for Autocorrelations

Null Hypothesis: no residual autocorrelations up to lag $\mathrm{h}$

Sample: 2000Q1 2013Q4

Included observations: 56

\begin{tabular}{|c|c|c|c|c|c|}
\hline Lags & Q-Stat & Prob. & Adj Q-Stat & Prob. & df \\
\hline $\mathbf{1}$ & 0.431431 & $\mathrm{NA}^{*}$ & 0.439275 & $\mathrm{NA}^{*}$ & $\mathrm{NA}^{*}$ \\
\hline $\mathbf{2}$ & 5.676856 & $N A^{*}$ & 5.878975 & $\mathrm{NA}^{*}$ & $\mathrm{NA}^{*}$ \\
\hline $\mathbf{3}$ & 15.16361 & 0.0865 & 15.90272 & 0.0689 & 9 \\
\hline
\end{tabular}

Note: *The test is valid only for lags larger than the VAR lag order.

$\mathrm{df}$ is degrees of freedom for (approximate) chi-square distribution

\section{Residual Heteroskedasticity Test}

VAR Residual Heteroskedasticity Tests:

No Cross Terms (only levels and squares)

Sample: 2000Q1 2013Q4

Included observations: 56

\begin{tabular}{|l|l|l|}
\hline Joint test: & & \\
\hline Chi-sq & df & Prob. \\
\hline $\mathbf{8 5 . 9 8 4 2 6}$ & 72 & 0.1246 \\
\hline
\end{tabular}




\begin{tabular}{|c|c|c|c|c|}
\hline Component & Skewness & Chi-sq & df & Prob. \\
\hline 1 & 0.205060 & 0.392463 & 1 & 0.5310 \\
\hline 2 & -0.951435 & 8.448797 & 1 & 0.0037 \\
\hline 3 & 0.307484 & 0.882431 & 1 & 0.3475 \\
\hline Joint & & 9.723690 & 3 & 0.0211 \\
\hline Component & Kurtosis & Chi-sq & df & Prob. \\
\hline 1 & 3.063460 & 0.009397 & 1 & 0.9228 \\
\hline 2 & 5.727904 & 17.36341 & 1 & 0.0000 \\
\hline 3 & 3.537222 & 0.673417 & 1 & 0.4119 \\
\hline Joint & & 18.04622 & 3 & 0.0004 \\
\hline Component & Jarque-Bera & df & Prob. & \\
\hline 1 & 0.401859 & 2 & 0.8180 & \\
\hline 2 & 25.81220 & 2 & 0.0000 & \\
\hline 3 & 1.555847 & 2 & 0.4594 & \\
\hline Joint & 27.76991 & 6 & 0.0001 & \\
\hline
\end{tabular}

\section{References}

Arlt, J., Guba, M., Radkovský, Š., Sojka, M., Stiller, V. (2001), "Selected Factors Influencing the Money Demand Development in 1994-2000." Politická Ekonomie, Vol. 49, No. 5, pp. 635-657.

Choi, K., Jung, C. (2009), "Structural Changes and the US Money Demand Function." Applied Economics, Vol. 41, No. 10, pp. 1251-1257, http://dx.doi.org/10.1080/00036840601007385

Coenen, G., Vega, J.-L. (1999), "The Demand for M3 in Euro Area." European Central Bank Working Paper No. 6.

Dickey, D. A., Fuller, W. A. (1979), “Distribution of the Estimators for Autoregressive Time Series with a Unit Root." Journal of the American Statistical Association, Vol. 74, No. 366, pp. 427-431, http://dx.doi.org/10.2307/2286348

Doornik, J. (1995), "Testing Vector Error Autocorrelation and Heteroscedasticity." Econometric Society 7th World Congress, Tokio.

Dreger, Ch., Wolters, J. (2014), "Money Demand and the Role of Monetary Indicators in Forecasting Euro Area Inflation." International Journal of Forecasting, Vol. 30, No. 2, pp. 303-312, http://dx.doi.org/10.1016/j.ijforecast.2013.09.008 
Engle, R. F., Granger, C. W. J. (1987), "Cointegration and Error Correction: Representation, Estimation, and Testing." Econometrica, Vol. 55, No. 2, pp. 251-276.

Friedman, M. (1956), The Quantity Theory of Money: A Restatement. Chicago: The University of Chicago Press.

Hayo, B. (2000), "The Demand for Money in Austria." Empirical Economics, Vol. 25, No. 4, pp. 581-603, http://dx.doi.org/10.1007/s001810000035

Hendry, D. F., Juselius, K. (2000), “Explaining Cointegration Analysis: Part 1." Energy Journal, Vol. 21, No. 1, pp. 1-42, http://dx.doi.org/10.5547/ISSN0195-6574-EJ-Vol21-No1-1

Hendry, D. F., Juselius, K. (2001), “Explaining Cointegration Analysis: Part 2." Energy Journal, Vol. 22, No. 1, pp. 75-120, http://dx.doi.org/10.5547/ISSN0195-6574-EJ-Vol22-No1-4

Hossain, A. A. (2013), "How Stable Is the Broad Money Demand Function in Australia An Empirical Study." Journal of Applied Economics, Vol. 12, No. 1, pp. 7-25.

Hsing, Y., Jamal A. M. M. (2011), “The Demand for Money in a Simultaneous-Equation Framework." Economics Bulletin, Vol. 31, No. 2, pp. 1-5.

Johansen, S. (1995), Likelihood-Based Inference in Cointegrated Vector Autoregressive Models. New York: Oxford University Press.

Kolluri, B. R., Singamsetti, R., Wahab, M. (2012), "Short-Run and Long-Run Money Demand: Recent Evidence." Journal of Accounting and Finance, Vol. 12, No. 3, pp. 91-103.

Komárek, L., Melecký, M. (2004), “Money Demand in an Open Transition Economy." Eastern European Economics, Vol. 42, No. 5, pp. 73-94.

Krugman, P., Obstfeld, M., Melitz, M. (2012), International Economics: Theory and Policy. Boston: Addison-Wesley.

Lütkepohl, H. (1991), Introduction to Multiple Time Series Analysis. New York: Springer-Verlag.

Lütkepohl, H. (2005), New Introduction to Multiple Time Series Analysis. New York: Springer-Verlag.

MacKinnon, J. G., Haug, A. A., Michelis, L. (1999), “Numerical Distribution Functions of Likelihood Ratio Tests for Cointegration." Journal of Applied Econometrics, Vol. 14, No. 5, pp. 563-577, http://dx.doi.org/10.1002/ (SICI) 1099-1255(199909/10)14:5\%3C563::AID-JAE530\%3E3.3.CO;2-I

Rao, B. B., Kumar, S. (2007), "Structural Breaks, Demand for Money and Monetary Policy in Fiji." Pacific Economic Bulletin, Vol. 22, No. 2, pp. 53-62.

Sarwar, H., Sarwar, M., Waqas, M. (2013), "Stability of Money Demand Function in Pakistan." Economic and Business Review, Vol. 15, No. 3, pp. 197-212.

White, H. (1980), "A Heteroskedastic-Consistent Covariance Matrix Estimator and a Direct Test for Heteroskedasticity." Econometrica, Vol. 48, pp. 817-838. 